\section{References}

1 Dent, C E, British Medical fournal, 1969, 2, 1419.

2 Berry, E M, et al, British Medical fournal, 1973, 4, 640

${ }^{3}$ Payne, R B, et al, British Medical Fournal, 1973, 4, 643.

${ }^{4}$ Marshall, R W, and Nordin, B E C, British Medical fournal, 1974, 2, 729.

5 Parfitt, A M, British Medical fournal, 1974, 1, 520.

${ }^{6}$ Prior, M, and Peake, M, Australian fournal of Medical Technology, 1975, 6,5

${ }^{7}$ Pedersen, K O, Scandinavian fournal of Clinical and Laboratory Investigation, 1972, 30, 321.
${ }^{8}$ Payne, R B, Lancet, 1973, 2, 375.

${ }^{9}$ Berry, E M, et al, British Medical fournal, 1974, 2, 53.

${ }^{10}$ Hodkinson, H M, British Medical fournal, 1974, 2, 223.

11 Payne, R B, et al, British Medical fournal, 1974, 1, 393.

12 Payne, R B, et al, British Medical fournal, 1974, 2, 504.

13 Payne, R B et al, British Medical fournal, 1974, 3, 345.

${ }^{14}$ Christiansen, C, et al, Clinica Chimica Acta, 1975, 62, 65.

15 Husdan, H, et al, Clinical Chemistry, 1974, 20, 529.

${ }^{16}$ van Leeuwen, A M, Thomasse, C M, and Kapteyn, P C, Clinica Chimica Acta, 1961, 6, 550.

\title{
Effect on adrenal function of topically applied clobetasol propionate (Dermovate)
}

\author{
C F ALLENBY, R A MAIN, R A MARSDEN, C G SPARKES
}

outpatients. For these reasons we investigated the effects of treatment with clobetasol propionate in both inpatients and outpatients.

\section{Summary}

Thirty-nine patients (15 outpatients and 24 inpatients) with a variety of skin diseases affecting variable areas of the body surface were treated with clobetasol propionate ointment (Dermovate). Before and after treatment the adrenal response to an intramuscular injection of tetracosactrin was tested and additional 9 am plasma cortisol levels were measured at intervals during treatment. A satisfactory initial therapeutic response was achieved in almost all cases during the trial period. When more than $50 \mathrm{~g}$ of ointment a week was used a significant number of patients developed adrenal suppression. When less than $50 \mathrm{~g}$ per week was used any suppression tended to be transient, and cortisol levels recovered as treatment progressed.

\section{Introduction}

It is well recognised that when corticosteroids are applied to the skin there may be sufficient percutaneous absorption to affect hypothalamic-pituitary-adrenal (HPA) function. This effect seems to parallel topical anti-inflammatory activity and is more likely to occur when large quantities of cream or ointment are applied to extensive areas of diseased skin.

Clobetasol propionate in a strength of $0.05 \%$ (Dermovate) is a highly effective corticosteroid preparation. ${ }^{1}$ Walker et al have shown that it has little effect on the HPA axis of outpatients when applied topically. ${ }^{2}$ They assessed adrenal function by estimating plasma cortisol levels at the beginning and end of treatment. But cortisol values during the early treatment period, when maximum absorption is most likely, were not measured. Furthermore, inpatients, whose lesions are usually more extensive, require larger amounts of steroid preparation than

Department of Dermatology, Lister Hospital, Hertfordshire

C F ALLENBY, MB, MRCP, consultant dermatologist

Department of Dermatology, Aberdeen Royal Infirmary, Aberdeen R A MAIN, MB, FRCP, consultant dermatologist and honorary senior lecturer

R A MARSDEN, MB, MRCP, registrar in dermatology (present address: Slade Hospital, Headington, Oxford)

Clinical Research Unit, Glaxo Laboratories Ltd, Greenford, Middle-

sex

C G SPARKES, BSC, PHD, clinical pharmacologist

\section{Patients and methods}

Twenty-three patients with psoriasis, 15 with dermatitis, and one with lichen planus were included. Children and patients who had received systemic steroid treatment during the previous six months were excluded. Ointment was applied to lesions up to twice daily without the use of occlusion (except in case 11). At the end of treatment the amount of ointment used was calculated.

HPA function in all patients was investigated using the short tetracosactrin test described by Wood et al, ${ }^{3}$ and 9 am plasma cortisol levels were assessed. Cortisol levels were considered abnormal if they were below $166 \mathrm{nmol} / 1(6 \mu \mathrm{g} / 100 \mathrm{ml})$. An abnormal response to an injection of $250 \mu \mathrm{g}$ of tetracosactrin was recorded if after 30 minutes plasma cortisol levels had not risen by at least $193 \mathrm{nmol} / 1(7 \mu \mathrm{g} / 100 \mathrm{ml})$ to a level of $552 \mathrm{nmol} / \mathrm{l}(20 \mu \mathrm{g} / 100 \mathrm{ml})$ or more. Plasma cortisol estimations were carried out in the same laboratory using a fluorimetric method described by Spencer-Peet et al. ${ }^{4}$

The extent of the disease was graded as follows: grade 1, small circumscribed lesions-for example, on elbows, knees, and scalp; grade 2 , under $50 \%$ of body surface affected; grade 3 , over $50 \%$ of body surface affected; grade 4 , almost confluent lesions.

\section{Results}

The results are given in table I. The ages of the 39 patients ranged from 15 to 79 years (median 48 years). There were 19 women and 20 men. Fifteen were treated as outpatients and 24 were inpatients. In most cases about half of the skin surface was treated. Only one patient (case 12) failed to improve. During treatment two patients developed an acneform rash.

\section{ADRENAL FUNCTION}

Adrenal function remained normal throughout the trial in only 14 patients (10 outpatients and 4 inpatients). Nineteen patients with initial normal 9 am plasma cortisol levels had abnormal levels for a variable period during treatment. In seven of these the plasma cortisol levels recovered, and in six of the seven the final tetracosactrin test was also normal. Of the 12 patients with depressed cortisol levels at the end of the trial half had an abnormal response to tetracosactrin.

Eight patients had a poor response to tetracosactrin at the beginning of the trial, and in four the 9 am plasma cortisol level was also abnormal. Evidence of improving adrenal function was present in three patients at the end of the trial (cases 17, 18, and 34). These eight patients had probably used large amounts of topical corticosteroids before starting the trial. 
TABLE I-Clinical details and cortisol levels in outpatients (cases 1-15) and inpatients (cases 16-39)

\begin{tabular}{|c|c|c|c|c|c|c|c|c|c|c|}
\hline \multirow{3}{*}{$\begin{array}{l}\text { Case } \\
\text { No }\end{array}$} & \multirow{3}{*}{ Disease } & \multirow{3}{*}{$\begin{array}{l}\text { Extent of } \\
\text { disease } \\
\text { (grade) }\end{array}$} & \multirow{3}{*}{$\underset{\text { result }}{\text { Clinical }}$} & \multirow{3}{*}{$\begin{array}{l}\text { Quantity of } \\
\text { ointment used } \\
\text { (g/week) }\end{array}$} & \multicolumn{6}{|c|}{ Plasma cortisol (nmol/l) } \\
\hline & & & & & \multicolumn{2}{|c|}{ Day 0} & \multirow{2}{*}{$\begin{array}{l}\text { Values on other days } \\
\text { (day given in } \\
\text { parentheses) }\end{array}$} & \multicolumn{3}{|c|}{ Final day } \\
\hline & & & & & $9 \mathrm{am}$ & $\begin{array}{c}30 \mathrm{~min} \\
\text { after } \\
\text { tetracosactrin }\end{array}$ & & Day & $9 \mathrm{am}$ & $\begin{array}{c}30 \mathrm{~min} \\
\text { after } \\
\text { tetracosactrin }\end{array}$ \\
\hline $\begin{array}{l}1 \\
2\end{array}$ & $\begin{array}{l}\text { Psoriasis } \\
\text { Acute } \\
\text { dermatitis }\end{array}$ & $\begin{array}{l}1 \\
1\end{array}$ & $\begin{array}{l}\text { Improved } \\
\text { Healed }\end{array}$ & $\begin{array}{l}23 \\
18\end{array}$ & $\begin{array}{l}312 \\
353\end{array}$ & $\begin{array}{l}933 \\
875\end{array}$ & & $\begin{array}{l}27 \\
27\end{array}$ & $\begin{array}{l}373 \\
248\end{array}$ & $\begin{array}{r}1087 \\
869\end{array}$ \\
\hline $\begin{array}{r}3 \\
4 \\
5 \\
6 \\
7 \\
8 \\
9 \\
10 \\
11 \\
12\end{array}$ & $\begin{array}{l}\text { Dermatitis } \\
\text { Psoriasis } \\
\text { Psoriasis } \\
\text { Psoriasis } \\
\text { Psoriasis } \\
\text { Psoriasis } \\
\text { Psoriasis } \\
\text { Psoriasis } \\
\text { Dermatitis } \\
\text { Atopic } \\
\text { dermatitis }\end{array}$ & $\begin{array}{l}1 \\
2 \\
2 \\
2 \\
2 \\
2 \\
2 \\
2 \\
2 \\
2\end{array}$ & $\begin{array}{l}\text { Improved } \\
\text { Improved } \\
\text { Improved } \\
\text { Healed } \\
\text { Improved } \\
\text { Improved } \\
\text { Improved } \\
\text { Improved } \\
\text { Improved } \\
\text { Static }\end{array}$ & $\begin{array}{r}30 \\
29 \\
26 \\
25 \\
37 \\
125 \\
100 \\
87 \\
16 \\
41\end{array}$ & $\begin{array}{l}298 \\
618 \\
342 \\
367 \\
464 \\
315 \\
342 \\
414 \\
635 \\
414\end{array}$ & $\begin{array}{l}624 \\
952 \\
698 \\
599 \\
999 \\
817 \\
817 \\
745 \\
878 \\
773\end{array}$ & (10) $77,(18) 30$ & $\begin{array}{r}10 \\
18 \\
24 \\
31 \\
14 \\
7 \\
14 \\
14 \\
13 \\
14\end{array}$ & $\begin{array}{l}582 \\
466 \\
400 \\
257 \\
491 \\
110 \\
353 \\
14 \\
751 \\
290\end{array}$ & $\begin{array}{l}947 \\
745 \\
828 \\
673 \\
850 \\
331^{*} \\
696 \\
196^{*} \\
905 \\
781\end{array}$ \\
\hline $\begin{array}{l}13 \\
14 \\
15 \\
16 \\
17 \\
18 \\
19 \\
20 \\
21 \\
22\end{array}$ & $\begin{array}{l}\text { Psoriasis } \\
\text { Psoriasis } \\
\text { Dermatitis } \\
\text { Dermatitis } \\
\text { Psoriasis } \\
\text { Psoriasis } \\
\text { Psoriasis } \\
\text { Lichen simplex } \\
\text { Psoriasis } \\
\text { Nummular } \\
\text { dermatitis }\end{array}$ & $\begin{array}{c}2 \\
3 \\
4 \\
1-2 \\
2 \\
2 \\
2 \\
2 \\
2 \\
2\end{array}$ & $\begin{array}{l}\text { Improved } \\
\text { Improved } \\
\text { Healed } \\
\text { Healed } \\
\text { Healed } \\
\text { Healed } \\
\text { Healed } \\
\text { Improved } \\
\text { Improved } \\
\text { Improved }\end{array}$ & $\begin{array}{r}72 \\
78 \\
159 \\
70 \\
23 \\
39 \\
48 \\
44 \\
50 \\
25\end{array}$ & $\begin{array}{l}707 \\
552 \\
356 \\
483 \\
502 \\
149 \\
497 \\
215 \\
284 \\
444\end{array}$ & $\begin{array}{l}839 \\
662^{*} \\
662 \\
878 \\
607^{*} \\
403^{*} \\
745 \\
914\end{array}$ & $\begin{array}{l}\text { (4) } 135 \\
\text { (8) } 55,(15) 30,(17) 119 \\
\text { (8) } 108,(16) 119 \\
\text { (6) } 364,(17) 480 \\
\text { (2) } 287,(5) 130 \\
\text { (3) } 108, \text { (5) } 108,(6) 97 \\
\text { (4) } 226, \text { (5) } 251,(6) 193\end{array}$ & $\begin{array}{r}14 \\
14 \\
7 \\
8 \\
36 \\
18 \\
22 \\
8 \\
7 \\
8\end{array}$ & $\begin{array}{r}718 \\
284 \\
55 \\
88 \\
326 \\
179 \\
508 \\
276 \\
160 \\
505\end{array}$ & $\begin{array}{l}759 \\
425^{*} \\
168^{*} \\
348^{*} \\
696 \\
546 \\
762 \\
580 \\
392^{*} \\
304^{*}\end{array}$ \\
\hline $\begin{array}{l}23 \\
24 \\
25\end{array}$ & $\begin{array}{l}\text { Dermatitis } \\
\text { Psoriasis } \\
\text { Psoriasis }\end{array}$ & $\begin{array}{l}2 \\
3 \\
3\end{array}$ & $\begin{array}{l}\text { Healed } \\
\text { Healed } \\
\text { Almost } \\
\text { Healed }\end{array}$ & $\begin{array}{r}131 \\
43 \\
75\end{array}$ & $\begin{array}{r}39 \\
505 \\
420\end{array}$ & $\begin{array}{l}356^{*} \\
867 \\
696\end{array}$ & $\begin{array}{l}\text { (1) } 63 \\
\text { (8) } 69,(15) 61,(17) 342 \\
\text { (5) } 86,(7) 80\end{array}$ & $\begin{array}{r}7 \\
36 \\
19\end{array}$ & $\begin{array}{r}23 \\
273 \\
141\end{array}$ & $\begin{array}{l}229 \\
665 \\
199 * \\
693\end{array}$ \\
\hline 26 & $\begin{array}{l}\text { Psoriasis } \\
\text { Psoriasis }\end{array}$ & $\begin{array}{l}3 \\
3\end{array}$ & $\begin{array}{l}\text { Improved } \\
\text { Healed }\end{array}$ & $\begin{array}{l}75 \\
82\end{array}$ & $\begin{array}{l}422 \\
378\end{array}$ & $\begin{array}{l}740 \\
629\end{array}$ & $\begin{array}{l}\text { (2) } 116 \\
\text { (1) } 55,(4) 69,(6) 14 \text {, } \\
\text { (8) } 69\end{array}$ & $\begin{array}{r}21 \\
9\end{array}$ & $\begin{array}{l}284 \\
353\end{array}$ & $489 *$ \\
\hline 28 & Dermatitis & 2 & Healed & 70 & 524 & 828 & (1) 83, (3) 97, (4) 69 , & 7 & 28 & $392^{*}$ \\
\hline 29 & Psoriasis & 3 & Improved & 110 & 373 & 745 & (1) $52,(4) 0,(6) 0$ & 14 & 28 & $141^{*}$ \\
\hline 30 & Dermatitis & 3 & Improved & 125 & 643 & 941 & $\begin{array}{l}\text { (2) } 284,(3) 403,(5) 284, \\
\text { (7) } 268,(9) 304\end{array}$ & 10 & 273 & 682 \\
\hline $\begin{array}{l}31 \\
32 \\
33\end{array}$ & $\begin{array}{l}\text { Psoriasis } \\
\text { Psoriasis } \\
\text { Neuro- } \\
\text { dermatitis }\end{array}$ & $\begin{array}{l}3 \\
3 \\
3\end{array}$ & $\begin{array}{l}\text { Improved } \\
\text { Improved } \\
\text { Improved }\end{array}$ & $\begin{array}{l}142 \\
141 \\
175\end{array}$ & $\begin{array}{l}268 \\
500 \\
287\end{array}$ & $\begin{array}{l}789 \\
781 \\
891\end{array}$ & $\begin{array}{l}\text { (7) } 268,(9) 304 \\
\text { (1) } 309,(4) 295\end{array}$ & $\begin{array}{l}8 \\
8 \\
8\end{array}$ & $\begin{array}{r}94 \\
279 \\
213\end{array}$ & $\begin{array}{l}284^{*} \\
707 \\
635\end{array}$ \\
\hline 34 & $\begin{array}{l}\text { Annular lichen } \\
\text { planus }\end{array}$ & 3 & Improved & 208 & 127 & $489 *$ & $\begin{array}{l}\text { (1) } 80,(2) 121,(3) 119 \text {, } \\
\text { (4) } 163,(6) 282\end{array}$ & 8 & 496 & 726 \\
\hline $\begin{array}{l}35 \\
36\end{array}$ & $\begin{array}{l}\text { Psoriasis } \\
\text { Psoriasis }\end{array}$ & $\begin{array}{l}3 \\
3\end{array}$ & $\begin{array}{l}\text { Improved } \\
\text { Healed }\end{array}$ & $\begin{array}{l}236 \\
268\end{array}$ & $\begin{array}{r}806 \\
61\end{array}$ & $\begin{array}{l}969^{*} \\
505^{*}\end{array}$ & $\begin{array}{l}\text { (2) } 75,(5) 44 \\
\text { (1) } 61,(3) 0,(4) 0, \\
\text { (5) } 17,(6) 77,(7) 47, \\
\text { (10) } 77,(11) 30, \\
\text { (12) } 47\end{array}$ & $\begin{array}{r}8 \\
13\end{array}$ & $\begin{array}{l}58 \\
28\end{array}$ & $\begin{array}{l}251^{*} \\
144^{*}\end{array}$ \\
\hline $\begin{array}{l}37 \\
38 \\
39\end{array}$ & $\begin{array}{l}\text { Dermatitis } \\
\text { Dermatitis } \\
\text { Exfoliative } \\
\text { dermatitis }\end{array}$ & $\begin{array}{l}\mathbf{4} \\
\mathbf{4} \\
\mathbf{4}\end{array}$ & $\begin{array}{l}\text { Healed } \\
\text { Healed } \\
\text { Healed }\end{array}$ & $\begin{array}{l}159 \\
173 \\
175\end{array}$ & $\begin{array}{l}334 \\
687 \\
406\end{array}$ & $\begin{array}{l}784 \\
999 \\
502^{*}\end{array}$ & $\begin{array}{l}\text { (6) } 91 \\
\text { (1) } 94,(4) 149, \text {, (5) } 508 \\
\text { (2) } 113, \text {,4) } 38,(6) 14 \text {, } \\
\text { (7) } 41\end{array}$ & $\begin{array}{l}7 \\
6 \\
8\end{array}$ & $\begin{array}{r}63 \\
358 \\
41\end{array}$ & $\begin{array}{l}386^{*} \\
566 \\
199 *\end{array}$ \\
\hline
\end{tabular}

*Tetracosactrin test result was abnormal.
Conversion: SI to traditionul units-Cortisol: $1 \mathrm{nmol} / 1 \approx 0.036 \mu \mathrm{g} / 100 \mathrm{ml}$.

TABLE II-Plasma cortisol levels in relation to quantity of clobetasol propionate ointment used

\begin{tabular}{|c|c|c|c|c|}
\hline $\begin{array}{l}\text { Quantity of } \\
\text { ointment } \\
\text { used } \\
\text { (g/week) }\end{array}$ & $\begin{array}{c}\text { No of } \\
\text { patients }\end{array}$ & $\begin{array}{l}\text { No of patients } \\
\text { with normal } \\
\text { plasma cortisol } \\
\text { throughout } \\
\text { treatment }\end{array}$ & $\begin{array}{l}\text { No of patients } \\
\text { with normal } \\
\text { plasma cortisol } \\
\text { at end of } \\
\text { treatment but } \\
\text { showing earlier } \\
\text { lowering }\end{array}$ & $\begin{array}{l}\text { No of patients } \\
\text { with low } \\
\text { plasma cortisol } \\
\text { at end of } \\
\text { treatment }\end{array}$ \\
\hline \multicolumn{5}{|c|}{ Outpatients } \\
\hline $\begin{array}{l}<50 \\
>50\end{array}$ & $\begin{array}{l}9 \\
6\end{array}$ & $\begin{array}{l}8 \\
2\end{array}$ & $\begin{array}{l}1 \\
0\end{array}$ & $\begin{array}{l}0 \\
3\end{array}$ \\
\hline $\begin{array}{r}<50 \\
>50\end{array}$ & $\begin{array}{r}6 \\
18\end{array}$ & $1_{3}^{\text {Inpatien }}$ & $\begin{array}{l}4 \\
4\end{array}$ & $\begin{array}{r}0 \\
11\end{array}$ \\
\hline
\end{tabular}

In case 22 cortisol levels fell only moderately during treatment. The level in this patient on the last day $(505 \mathrm{nmol} / \mathrm{l})$ suggested that the value of plasma cortisol ( $304 \mathrm{nmol} / \mathrm{l})$ after tetracosactrin was wrong. Two patients were not tested with tetracosactrin before treatment (cases 21 and 22) but their 9 am cortisol levels were normal and the tetracosactrin test would probably also have been normal. Two patients (cases 11 and 13) did not show a normal rise in plasma cortisol after tetracosactrin but they were considered to be normal since their initial levels were high and a reasonable response was recorded.

\section{QUANTITY OF OINTMENT USED}

The results indicated that there was a relation between the amount of ointment used per week and plasma cortisol levels (table II). Most inpatients were using large quantities of ointment: only six of the 24 inpatients were using less than $50 \mathrm{~g}$ a week and all had normal cortisol levels at the end of treatment, with five having a normal response to tetracosactrin. Four of the six had reduced 9 am plasma cortisol levels, however, at some earlier stage of treatment. The 11 inpatients whose plasma cortisol levels were low at the end of treatment were all using more than $50 \mathrm{~g}$ per week. Nine of the 15 outpatients, on the other hand, were using less than $50 \mathrm{~g}$ a week, and again all had normal plasma cortisol levels with normal responses to tetracosactrin at the end of the treatment. The three outpatients with low plasma cortisol levels at the end of treatment were all using more than $50 \mathrm{~g}$ a week.

Those patients with the most extensive skin disease tended to use the most ointment.

\section{DURATION OF TREATMENT}

Eleven of the 15 outpatients were treated for 14 days or more compared with seven of the 24 inpatients.

Multiple 9 am plasma cortisol level estimations in inpatients showed that levels tended to slowly increase during treatment in about half the patients. The effect was not usually seen in patients using large quantities of ointment.

\section{Discussion}

The results show that if over $50 \mathrm{~g}$ of clobetasol propionate ointment is applied per week then adrenal suppression may occur. 
This is not surprising since suppression of HPA function in patients using topical steroid preparations is well recorded. James et $a l^{5}$ found that betamethasone valerate caused lowering of plasma cortisol levels when used with occlusion in inpatients. The same effect has been shown from triamcinolone acetonide without occlusion. ${ }^{6}$ Feiwel et al ${ }^{7}$ have shown that plasma cortisol levels in children treated as outpatients with betamethasone valerate tend to be low, although this is not so apparent with adults. Growth retardation, oedema, and Cushingoid features have been noted in babies and children receiving topical corticosteroids. ${ }^{8-10}$

Clobetasol propionate is a highly effective topical corticosteroid preparation. ${ }^{111} \mathrm{~A}$ six-month study comparing clobetasol propionate and fluocinolone acetonide in the treatment of psoriasis indicates that it may be even more effective than was shown by earlier short-term trials. ${ }^{12}$ It is reasonable to expect that the topical activity of a steroid is correlated with its ability to produce systemic effects, and this has been shown using animal models. ${ }^{13}$

Recent evidence suggests that prolonged application of a topical steroid in adult outpatients may not produce significant adrenal suppression. Wilson et $a^{14}$ studied plasma cortisol levels in 295 outpatients, $90 \%$ of whom were using betamethasone valerate, and concluded that only a few patients so treated would have abnormal HPA function. The use of the insulin stress test in Wilson et al's study and in our outpatient group might have shown abnormal HPA function not shown by simpler methods of assessment. Nevertheless, Munro and $\mathrm{Clift}^{15}$ used this more rigorous test in studying 40 outpatients comparable with those studied by Wilson et al $^{14}$ and concluded that there was little effect on adrenal function.

Our results show that when less than $50 \mathrm{~g}$ of clobetasol propionate ointment a week is used there may be transient suppression of HPA function, which apparently recovers as the skin heals. This is probably because less ointment is applied and the epidermal barrier is restored, thereby reducing corticosteroid absorption. ${ }^{6}{ }^{16}$ These observations may explain the results of Walker et al, ${ }^{2}$ who found that clobetasol propionate had little effect on plasma cortisol levels. In most of their patients $5 \%$ or less of the body surface area was diseased, and the patients used less than $50 \mathrm{~g}$ of ointment a week. It is also conceivable that the timing of their samples-at 14 and 28 days of treatment-allowed any early adrenal suppression to recover despite continuing treatment. This might also account for the apparent lack of systemic activity reported in the other studies cited.

When more than $50 \mathrm{~g}$ of clobetasol propionate ointment a week is being used clinicians should be aware of the possibility of adrenal suppression. In children these effects will probably occur with smaller quantities. While short-term adrenal suppression is probably of little clinical significance, long-term suppression should be prevented. Consequently, the most desirable method of using clobetasol propionate in many cases may be to give short intensive courses to induce rapid healing. The systemic and local side effects described by Staughton and August ${ }^{17}$ would then be avoided.

\section{References}

1 Sparkes, C G, and Wilson, L, British fournal of Dermatology, 1974, 90, 197. 2 Walker, S R, et al, British fournal of Dermatology, 1974, 91, 339.

3 Wood, J B, et al, Lancet, 1965, 1, 243.

4 Spencer-Peet, J, Daly, J R, and Smith, V, fournal of Endocrinology, 1965 $31,235$.

5 James, V H T, Munro, D D, and Feiwel, M, Lancet, 1967, 2, 1059.

${ }^{6}$ Keczkes, K, et al, British fournal of Dermatology, 1967, 79, 475.

${ }^{7}$ Feiwel, M, James, V H T, and Barnet, E S, Lancet, 1969, 1, 485.

${ }^{8}$ Benson, P F, and Pharaoh, P O D, Guy's Hospital Reports, 1960, 109, 212

9 Feinblatt, B I, et al, American Fournal of Diseases of Children, 1966, 112 , 218.

${ }^{10}$ Keipert, J A, and Kelly, R, Medical fournal of Australia, 1971, 1, 542.

11 Woodbridge, P, Practitioner, 1974, 212, 732.

12 Floden, $\mathrm{C} \mathrm{H}$, et al, to be published.

${ }^{13}$ Child, K J, et al, Archives of Dermatology, 1968, 97, 407.

14 Wilson, L, Williams, D I, and Marsh, S D, British fournal of Dermatology, $1972,88,375$.

15 Munro, D D, and Clift, D C, British fournal of Dermatology, 1973, 88, 381

${ }^{16}$ Scoggins, R B, and Kliman, B, New England fournal of Medicine, 1965, 273, 831 .

17 Staughton, R C D, and August, P J, British Medical fournal, 1975, 2, 419.

\section{PRELIMINARY COMMUNICATION}

\section{The monocystic ovary syndrome}

\section{J W DELAHUNT, R V CLEMENTS, I D RAMSAY, J NEWTON, W P COLLINS, J LANDON}

British Medical fournal, 1975, 4, 621-622

\section{Summary}

Three patients with oligomenorrhoea and hirsutism thought to have the polycystic ovary syndrome were

North Middlesex Hospital, London N18 1QX

J W DELAHUNT, MRCP, MRACP, research fellow

R V CLEMENTS, FRCS, MRCOG, consultant obstetrician and gynaecologist I D RAMSAY, MD, MRCP, consultant physician, Regional Endocrine Centre

King's College Hospital Medical School, London SE5

J NEWTON, MD, MRCOG, senior lecturer in obstetrics and gynaecology W P COLLINS, DSC, FRIC, senior lecturer in biochemistry

St Bartholomew's Hospital, London EC1

J LANDON, MRCP, MRCs, professor of chemical pathology found to have only one ovarian cyst. Endocrine findings were similar to those found in the polycystic syndrome, but apart from the single cyst the ovaries were histologically normal; a biopsy specimen of a cyst showed normal follicular appearances and no evidence of luteinisation. These cysts may be the cause of this condition, producing abnormal amounts of ovarian steroids which modify the pituitary response. Further studies are needed, however, to determine this possibility.

\section{Introduction}

The syndrome of oligomenorrhoea and hirsutism with polycystic changes in the ovaries has been recognised for many years, ${ }^{12}$ although in some cases no obvious ovarian changes are apparent. ${ }^{2} 3$ We report here, for the first time, three cases in which the only ovarian abnormality was a single, and possibly functional, cyst.

\section{Patients and methods}

The cases were selected from a study of patients likely to have the polycystic ovary syndrome. Hirsutism was estimated by a method on which $96 \%$ of a female outpatient population scored seven or below. No patient had clinical or biochemical evidence of thyroid, adrenal, 